\title{
Upaya Guru PAI dalam Pembentukan Akhlaqul Karimah di Sekolah Dasar
}

\author{
Nuraini $^{1}$, Rahmi Wiza ${ }^{2}$ \\ ${ }^{12}$ Fakultas Ilmu Sosial, Universitas Negeri padang \\ Corresponding author, e-mail: ainisesaa@gmail.com
}

\begin{abstract}
This study aims to determine the morals of students at the UNP Laboratory Development Elementary School, to find out the efforts of Religion teachers in providing examples, guidance, historical stories, encouragement, and fostering students' conscience and to know the supporting and inhibiting factors for teachers in shaping students' morality. This type of research is qualitative with descriptive method, because the research describes, tells, and interprets a situation or event as it is. The results of this study were that students still spoke in high-pitched voices, running around in front of the office, and their hair was still long. Efforts made by Religion teachers are a) Providing an example with Tahfiz, b) Encouraging performing Dzuhur prayers in congregation, c) Equipping common sense with knowledge through historical stories, d) Advising parents to get along with good people, e) Encouraging to leave the nature of lazy. The driving factors in the formation of akhlaq karimah are parents, student motivation, and the community. Meanwhile, the inhibiting factors in the formation of akhlaqul karimah are socioeconomic conditions and education level.
\end{abstract}

Keywords: Efforts, Religious Teachers, Akhlaqul Karimah

This is an open access article distributed under the Creative Commons 4.0 Attribution License, which permits unrestricted use, distribution, and reproduction in any medium, provided the original work is properly cited. (C) 2018 by author.

\section{Pendahuluan}

Pendidikan merupakan kebutuhan manusia. Pendidikan selalu mengalami perubahan, perkembangan dan perbaikan sesuai dengan perkembangan di segala bidang kehidupan. Perubahan dan perbaikan dalam bidang pendidikan meliputi berbagai komponen yang terlibat di dalamnya baik itu pelaksana pendidikan di lapangan (kompetensi guru dan kualitas tenaga pendidik), mutu pendidikan, perangkat kurikulum, sarana dan prasarana pendidikan dan mutu manejemen pendidikan termasuk perubahan dalam metode dan strategi pembelajaran yang lebih inovatif. Upaya perubahan dan perbaikan tersebut bertujuan membawa kualitas pendidikan Indonesia lebih baik.

Menurut Ihsan, (2007:16) menjelaskan bahwa pendidikan Agama Islam adalah menanamkan akhlaqul yang mulia didalam jiwa anak pada masa pertumbuhannya dan menyiraminya dengan air petunjuk dan nasihat, sehingga akhlaq itu menjadi salah satu kemampuan (meresap dalam) jiwanya kemudian buahnya berwujud dalam keutamaan, kebaikan dan cinta bekerja untuk kemanfaatan tanah air. Oleh karena itu, Pendidikan Agama Islam sekaligus merupakan pendidikan amal serta karena ajaran Islam berisi tentang ajaran sikap dan tingkahlaku pribadi masyarakat menuju kesejahteraan hidup perorangan dan bersama, maka orang pertama yang bertugas mendidik masyarakat adalah para Nabi dan Rasul, selanjutnya para ulama dan cerdik pandai sebagai penerus tugas dan kewajiban mereka. Pengertian yang lebih sederhana tentang pendidikan karakter adalah hal positif apa saja yang dilakukan oleh guru dan berpengaruh kepada karakter siswa yang diajarnya.

Mendidik Akhlaqul Karimah pada siswa/i merupakan titik awal anak dikarenakan untuk memiliki kepribadian baik, sehingga dapat menjadi anak saleh. Dalam hal ini peran dan figur dari seorang pendidik atau seorang guru menjadi tonggak dalam pembentukan akhlaqul karimah pada anak didik. Segala perbuatan dan tingkah laku pendidik atau guru akan ditiru oleh anak didiknya. Ibaratnya, seorang guru digugu dan ditiru segala 
tindakannya. Menjadi seorang guru tidak mudah karena selain mempunyai kompetensi akademik juga harus memiliki kepribadian yang mulia. Menurut pendapat dari Oemar Hamalik (2014:12) menjelaskan bahwa guru adalah suatu profesi, artinya suatu jabatan tersendiri yang memerlukan keahlian sebagai guru. Kendatipun masih ada yang berpandangan, bahwa pekerjaan guru dapat dilaksanakan oleh setiap orang. Tetapi, itu tidak berarti bahwa orang itu memiliki profesi keguruan, dan akan nampak nyata dalam hasil-hasil pekerjaannya.

Nurfuadi (2012:109:110) mengatakan bahwa akhlaq mulia yang yang harus dicerminkan dalam kehidupannya adalah sikap bersabar menghadapi suatu persoalan, berdisiplin dalam menunaikan tugas, jujur dalam menyelesaikan pekerjaan, sikap adil kepada semua orang, tidak pilih kasih, mampu menjalin kerjasama dengan orang lain, gembira memberikan pertolongan kepada orang lain, menunjukkan kepedulian sosial yang tinggi, dan lain-lain. Akhlaqul Karimah (mahmudah) adalah segala tingkah laku yang terpuji (yang baik) yang biasa juga dinamakan "fadilah" (kelebihan). Imam Alghozali menggunakan juga perkataan "mun'jiat" yang berarti segala sesuatu yang memberikan kemenangan atau kejayaan.

Upaya mendidik anak-anak menjadi pribadi yang baik, perlu diwujudkan bersama sebagai prioritas dalam hubungan kerjasama antara keluarga, masyarakat maupun pemerintah khususnya melalui bidang pendidikan. Sejalan dengan apa yang diamanatkan oleh negara Indonesia dalam Pasal 3, Undang-Undang No. 20 Tahun 2003 tentang Sistem Pendidikan Nasional bahwa: pendidikan nasional berfungsi mengembangkan dan membentuk watak serta peradaban bangsa yang bermartabat dalam rangka mencerdaskan kehidupan bangsa, bertujuan untuk berkembangnya potensi peserta didik agar menjadi manusia yang beriman, bertakwa kepada Tuhan Yang Maha Esa, berakhlak mulia, sehat, berilmu, cakap, kreatif, mandiri dan menjadi warga negara yang demokratis serta bertanggung jawab.

Proses yang dilakukan dalam membentuk Akhlaqul Karimah melalui beberapa kegiatan keagamaan ada di SD Pembangunan Laboratorium UNP, misalnya melalui kegiatan mengaji diniyah, dalam mengaji diniyah itu terdapat beberapa pelajaran seperti baca tulis alqur'an (BTA), tajwid, fiqih, akhlak, tauhid, kewanitaan, tadarus (Al-Qur'an), shalat berjama'ah, tafsir Al-Qu'an, hafalan juz'amma, kultum, bimbingan (bimbingan langsung dan bimbingan tidak langsung), shalat tahajud, puasa senin dan kamis, dan pengajian.

Sekolah Dasar Pembangunan Laboratorium UNP adalah sekolah swasta di Kota Padang yang dikelola oleh Universitas Negeri Padang. Tidak hanya Sekolah Dasar Pembangunan Laboratorium UNP saja yang dikelola oleh Universitas Negeri Padang. Universitas Negeri Padang juga mengelola terdiri dari tingkat TK/PAUD, SMP dan SMA. Laboratorium UNP dirintis pada tanggal 6 Mei 2009 dengan nama Sekolah Pembangunan KORPRI UNP Padang sejak tahun 1990 sampai tahun 2009. Sekarang Laboratorium Pembangunan UNP ini sudah beralih pengelolaan langsung dibawah UNP dengan nama baru Sekolah Dasar Pembangunan Laboratorium UNP Padang.

Alasan peneliti meneliti di SD Pembangunan Laboratorium UNP dikarenakan visi misi sejalan dengan pembentukan akhlaqul karimah yaitu terwujudnya lulusan yang cerdas, berbudaya, berakhlak, beriman dan bertaqwa. Pembentukan Akhlaq merupakan salah satu tujuan dilaksanakannya pendidikan di SD Pembangunan Laboratorium UNP.

Berdasarkan permasalahan-permasalahan yang telah diuraikan diatas, maka penulis tertarik untuk melakukan penelitian di SD Pembangunan Laboratorium Universitas Negeri Padang dengan judul yang diajukan dalam skripsi ini yaitu "Upaya Guru Pendidikan Agama Islam Dalam Pembentukan Akhlaqul Karimah di SD Pemabangunan Laboratorium Universitas Negeri Padang"

\section{Metode}

Jenis penelitian ini adalah kualitatif dengan metode deskriptif, karena penelitian menggambarkan, menuturkan, dan menafsirkan suatu keadaan atau peristiwa sebagaiamana adanya. Kirk dan Miller (dalam Moleong, 2006:3) menjelaskan penelitian kualitatif merupakan tradisi tertentu dalam ilmu pengetahuan sosial secara fundamental yang 
bergantung pada pengamatan pada manusia dalam kawasannya sendiri dan berhubungan dengan orang-orang tersebut dalam bahasanya dan dalam peristilahannya. Menurut Sugiyono (2013:49-53) mengemukakan penelitian deskriptif tidak dimaksudkan untuk menguji hipotesis tertentu, tetapi hanya menggambarkan apa adanya tentang suatu variabel, gejala atau keadaan. Dengan demikian penelitian kualitatif dengan metode deskriptif adalah metode penelitian yang bertujuan untuk membuat deskriptif atau gambaran secara sistematis, mendalam dan akurat mengenai fakta-fakta serta hubungan antara fenomena yang diteliti.

Penelitian kualitatif dengan metode deskriptif untuk menggambarkan latar pengamatan, tindakan, orang dan pembicaraan yang diperoleh dilapangan. Penggunaan metode ini akan berpeluang bagi peneliti untuk mengumpulkan data yang bersumber dari observasi, wawancara, catatan lapangan, foto, dokumen pribadi, catatan, dan dokumen resmi guna menggambarkan subjek penelitian.

Sesuai dengan jenis data yang peneliti kumpulkan, maka sumber data primer adalah data yag didapatkan dari informan penelitian secara langsung. Sedangkan sumber data sekunder diperoleh dari data-data yang didapatkan dari lembaga pendidikan SD Pembangunan Laboratorium, Universitas Negeri Padang. Dalam pengumpulan data Peneliti menggunakan tiga metode pengumpulan data kualitatif yaitu observasi, wawancara dan studi dokumentas.

\section{Hasil dan Pembahasan}

Pendidikan Akhlak merupakan pendidikan yang dilakukan oleh guru untuk menanamkan nilai-nilai ataupun norma-norma terkait budi pekerti yang meliputi komponen pengetahuan, kesadaran atau kemauan, dan tindakan untuk melaksanakan nilai-nilai tersebut. Pembentukan Akhlaqul Karimah sangat penting ditanamkan kepada siswa sejak dini dikarenakan hal tersebut melandasi kepribadian yang baik dalam interaksi sosial serta kehidupan sehari-harinya sebagai pribadi yang santun, jujur,, memiliki rasa empati yang tinggi terhadap sesama.

Penelitian ini merupakan penelitian di lapangan atau field research yang bersifat kualitatif deskriptif yang mengambil lokasi di SD Pembangunan Laboratorium UNP yang mana objek penelitiannya adalah pendidikan Akhlaqul Karimah. Pada penelitian ini mengangkat judul "Upaya Guru PAI dalam Pembentukan Akhlaqul Karimah di Sekolah Dasar". Penelitian pernah dilakukan oleh Purnama Sagala (2021) dalam skripsinya yang berjudul "Upaya Guru Pendidikan Agama Islam dalam Membentuk Akhlakul Karimah Peserta Didik di Sekolah Dasar Negeri 07 Panai Hilir Kecamatan Panai Hilir Kabupaten Labuhanbatu" yang menyimpulkan bahwa upaya guru Pendidikan Agama Islam dalam membentuk Akhlaqul Karimah peserta didik dalah dengan memberikan contoh keteladanan, memberikan pembiasaan, memberikan nasehat, melakukan pengawasan, kegiatan keagamaan, metode kisah, memberikan kasih sayang serta pujian kepada peserta didik. Penelitian ini berhasil dilaksanakan oleh Purnama Sagala, maka penelitipun tertarik meneliti penelitian ini.

\section{Akhlaqul Karimah Siswa di SD Pembangunan Laboratorium UNP}

SD Pembangunan Laboratorium UNP memiliki Suasana lingkungan belajar yang kondusif, penuh dengan nuansa kekeluargaan serta ramah lingkungan menjadi ciri khas SD Pembangunan Laboratorium UNP sebagai sekolah. Selain itu, sopan dalam perbuatan serta santun dalam perkataan tercermin dari segenap warga sekolah, baik guru, karyawan serta siswa. Kondisi tersebut semakin memperkuat keyakinan peneliti bahwa akhlak keseharian siswa di SD Pembangunan Laboratorium UNP suasana kekeluargaan semakin terlihat pada saat mereka berinteraksi dengan teman sejawat. Hasil wawancara juga menunjukkan bahwa diawal siswa masuk ke SD Pembangunan Laboratorium UNP, hal itu tidak terlihat sepenuhnya dari siswa, semisal masih mudah dijumpai siswa yang bertutur kata dengan nada tinggi, berlari-lari di depan kantor dan bahkan ada yang rambutnya masih panjang dan ada pula yang memakai anting. 
Selain itu, juga terdapat beberapa anak yang masih melanggar aturan sekolah, seperti bolos, berpacaran serta kurang menghormati guru dan segenap warga sekolah. Hal ini menjadi perhatian khusus bagi guru Pendidikan Agama Islam SD Pembangunan Laboratorium UNP untuk mengadakan pembinaan khusus bagi siswa yang dipandang belum berakhlaqul karimah, dengan serangkaian kegiatan dan pembiasaan yang ditempuh selama satu semester. Proses pembinaan dan adaptasi diperlukan karena akhlak yang kurang baik para siswa ini dilatarbelakangi oleh pengaruh lingkungan dan kebiasaan sebelum masuk ke SD Pembangunan Laboratorium UNP.

Hal demikian dikarenakan SD Pembangunan Laboratorium UNP tidak terlalu menyeleksi calon siswa yang hendak mendaftar, bahkan penerimaan siswa baru dibuka lebih awal dari pada sekolah lain membuka pendaftaran, setelah kuota antara 75-90 terpenuhi maka pendaftaran ditutup. Dengan demikian, proses seleksi tetap dilaksanakan sebagai komitment status kelembagaan. Adapun pola tes yang diterapkan di SD Pembangunan Laboratorium UNP dua hal, yaitu tes akademik dan tes psikologi. Hal ini membuktikan bahwa tidak SD Pembangunan Laboratorium UNP mementingkan kuantitas, akan tetapi lebih mementingkan kualitas.

\section{Upaya Guru pendidikan Agama Islam dalam memberikan keteladanan, tuntunan, kisah sejarah, dorongan, dan memupuk hati nurani siswa}

\section{a. Upaya Guru Pendidikan Agama Islam Memberikan Contoh Keteladanan Melalui Kegiatan Tahfiz}

Pembinaan baca bi At-Tartil di SD Pembangunan Laboratorium UNP menggunakan metode Tartila, berlangsung setiap pagi pada pukul 06.30 WIB dibina oleh beberapa ustadz dan ustadzah sesesuai dengan jenjang yang telah dikelompokkan oleh dewan guru. Kegiatan ini merupakan kegiatan yang wajid diikuti oleh seluruh peserta didik dan juga sebagai kegiatan yang paling mendasar dalam Tahfiz, bagi peserta didik yang telah menuntaskan seluruh kegiatan pada kegiatan baca Bi At-Tartil maka dapat melanjutkan pada jenjang selanjutnya yaitu tahap Tahfidzul Qur'an dan tahap yang paling terakhir yaitu Mu'allimul Qur'an.

Adapun tempat kegiatan pembelajaran baca Bi At-Tartil dilaksanakan di beberapa tempat seperti ruang kelas, aula, mushalla, joglo sekolah, perpustakaan, ruang lap komputer dan ruang makan atau kantin. Pembinaan baca bi At-tartil di SD Pembangunan Laboratorium UNP. Dalam pelaksanaan kegiatan Tahfiz ini guru memberikan keteladanan melalui cara hadir awal sebelum siswa-siswi berkumpul, sambil membaca surah-surah pendek bit-tartil yang kemudian diikuti oleh para siswa yang baru datang. Hal ini terlihat dari apa yang disampaikan oleh salah satu pengajar Alquran

Berdasarkah hasil wawancara peneliti dilapangan maka peneliti dapat menyimpulkan bahwa sosok guru adalah teladan bagi siswanya, maka guru wajib menerapkan sikap yang baik seperti mencontohkan sikap datang tepat waktu sebelum pelaksanaan kegiatan Tahfiz dimulai sehingga siswa merasa malu jika datang terlambat.

\section{b. Guru Penddikan Agama Islam Mendorong Siswa Agar Melaksanakan Shalat Dzuhur Berjamaah}

Selain pembiasaan salat dhuha berjamaah, di SD Pembangunan Laboratorium UNP juga dibiasakan dengan salat dzuhur dan ashar berjamaah. Hal ini dimaksudkan selain melatih kebersamaan dan kekeluargaan juga sebagai praktik dari materi Pendidikan Agama Islam serta pembiasaan melaksanakan salat di awal waktu dan berjamaah. Shalat dzuhur berjamaah dilaksanakn pada agenda ishoma pukul 11:30 Wib berbarengan dengan masuknya waktu salat dzuhur.

Dalam pelaksanaannya, salat dhuhur berjamaah juga dilaksanakan di mushalla. Namun, kegiatan ini dilaksanakan secara bergantian antara jamaah siswa dan jamaah siswi. Terlebih dahulu kegiatan dilaksanakan oleh jamaah putra dengan dipimpin oleh guru Pendidikan Agama Islam, kemudian dilanjutkan dengan kegiatan salat berjamaah 
para siswi dengan dipimpin oleh ustadzah. Sebagai bagian upaya menanamkan tanggung jawab serta pembiasaan yang baik, kegiatan ini tidak sepenuhnya dipimpin oleh imam shalat. Dalam hal ini, seorang imam hanya memandu jalannya salat berjamaah. Sedangkan yang adzan, membaca surat-surat pendek sebelum shalat, wirid serta doa bersama setelah salat dipimpin oleh seorang siswa atau siswi yang memang sudah ditunjuk sebelumnya, kemudian dilanjutkan dengan kultum berbahasa inggris oleh seorang siswa pula.

Shalat dzuhur berjamaah ini terlebih dahulu diawali dengan salat sunnah dua rakat oleh semua jamaah. Dalam kegiatan ini, mereka sudah terbiasa dan tidak perlu dipandu oleh guru Pendidikan Agama Islam. Kemudian, diakhiri dengan shalat sunnah dua rakaat yang kemudian dilanjutkan dengan berjabatan tangan dengan guru Pendidikan Agama Islam yang sekaligus jadi imam secara bergiliran sambil membaca shalawat.

Berdasarkan hasil wawancara peneliti dilapangan maka peneliti dapat menyimpulkan bahwa pelaksanaan sholat dzuhur berjamaah di SD Pembangunan Laboratorium UNP merupakan kegiatan rutin yang harus dilaksanaka oleh siswa siswi dan nanti diakhiri dengan sholat sunnah 2 rakaat sehingga siswa siswi dapat menyadari bahwa pentingnya mengerjakan sholat 5 waktu dalam kehidupan sehari-hari.

\section{c. Guru Pendidikan Agama Islam Membekali Akal Pikiran Siswa Dengan Ilmu Pengetahuan Melalui Kisah Sejarah}

Salah satu upaya guru Pendidikan Agama Islam di SD Pembangunan Laboratorium UNP dalam pembentukan akhlak yang dilakukan adalah memberikan bekal ilmu pengetahuan untuk mengisi akal pikiran siswa. Pemberian bekal ilmu pengetahuan dilakukan dengan cara selain memberikan materi pokok juga memberikan materi tambahan seperti ilmu tauhid, fiqih, akhlak, dan sejarah Islam. Hal ini dilakukan agar siswa mempunyai pengetahuan cukup tentang ajaran-ajaran agama Islam yang berfungsi sebagai bekal amalan sehari-hari.

Pembelajaran sejarah sebagai pendukung pendidikan Akhlaqul Karimah memiliki peran yang sangat sentral karena pembelajaran sejarah memiliki lingkup materi seperti meneladani nilai-nilai heroic, keteladanan, patriotisme dan semangat pantang menyerah yang mendasari proses pembentukan karakter dan kepribadian siswa. Pembelajaran sejarah mengandung ajaran dan kebijaksanaan moral yang berguna dalam mengatasi krisis multidimensi yang dihadapi dalam kehidupan sehari-hari.

Berdasarkan hasil wawancara peneliti dilapangan maka dapat disimpulkan bahwa dalam membekali akal pikiran siswa. SD Pembangunan Laboratorium UNP menggunakan kisah sejarah yang contohnya adalah Nabi Muhammad Saw sehingga siswa siswi dapat meneladai akhlaknya dalam memperjuangkan kebenaran.

\section{d. Guru Pendidikan Agama Islam Menyarankan Kepada Orang tua Siswa Agar anak bergaul denagn Orang - Orang baik}

Dalam pembentukan akhlak siswa, guru Pendidikan Agama Islam SD Pembangunan Laboratorium UNP mengupayakan agar sedapat mungkin siswa dapat bergaul dengan orang-orang yang baik. Hal ini terkait dengan sifat siswa yang senang mencontoh lingkungan dan mudah dipengaruhi. Dengan mengupayakan siswa bergaul dengan orang orang yang baik, diharapkan mereka mendapatkan pengaruh yang baik dari orang-orang yang baik itu. Upaya guru tersebut dilakukan dengan cara berkomunikasi dan bekerjasama dengan orang tua siswa. Komunikasi dan kerjasama dilakukan agar guru dapat memantau siswa, baik saat berada di rumah, maupun di luar rumah.

Berdasarkan hasil wawancara peneliti dilapangan maka peneliti dapat menyimpulkan bahwa guru Pendidikan Agama Islam di SD Pembangunan Laboratorium UNP menyarankan kepada orangtua agar memastikan anaknya bergaul dengan orang baik sehingga sikap dan prilaku anak dapat menjadi baik. 


\section{e. Guru Pendididkan Agama Islam Mendorong Siswa Untuk Meninggalkan Sifat Pemalas}

Terkait dengan sifat pemalas ini, beberapa siswa mengiyakan bahwa mereka terkadang malas untuk belajar dan berangkat sekolah. Rasa malas ini biasanya timbul karena siswa merasa lelah setelah beraktifitas seharian. Wujud kemalasan itu misalnya tidak mengerjakan PR, absen dan membolos pada jam pelajaran tertentu. Untuk menghadapi sifat malas siswa, guru memberikan sanksi bagi siapa saja yang melanggar peraturan di kelas. Sanksi diberikan dalam bentuk pemberian tugas. Guru juga selalu menekankan pada setiap pertemuan di dalam kelas, agar siswa selalu berdisiplin dan membiasakan sikap tersebut di kehidupan sehari-hari.

Berdasarkan hasil wawancara peneliti dilapangan maka peneliti dapat menyimpulkan bahwa guru Pendidikan Agama Islam di SD Pembangunan Laboratorium UNP selalu menasehati siswanya agar dapat meninggalkan sikap malas karna orang yang sukses adalah orang yang giat belajar dan berusaha.

\section{Faktor Pendukung Dan Penghambat Bagi Guru Dalam Membentuk Akhlaqul Karimah Siswa}

\section{a. Faktor Pendorong}

Faktor pendorong dalam pembentukan akhlak siswa di SD Pembangunan Laboratorium UNP antara lain, sebagai berikut:

\section{1) Orang Tua}

Orang tua adalah pembina pribadi yang utama dalam hidup anak, kepribadian orang tua, sikap dan cara hidup mereka merupakan unsur-unsur pendidikan yang tidak langsung, yang dengan sendirinya akan masuk ke dalam pribadi anak yang sedang tumbuh. Terkait dengan hal ini, maka orang tua yang baik kemungkinan besar akan menghasilkan anak yang baik pula. Dengan mendidik dan membiasakan anak untuk hidup sesuai dengan ajaran agama, salah satunya dengan cara memasukan anak ke madrasah diniyah dan atau ke pesantren diharapkan anak-anak akan menjadi generasi yang berakhlak baik.

\section{2) Motivasi Siswa}

Motivasi siswa dalam pembelajaran pendidikan agama Islam sangatlah penting karena berkaitan erat dengan semangat serta kegairahan seseorang untuk melakukan sesuatu. Motivasi siswa dalam mengikuti pembelajaran Pendidikan Agama Islam di kelas merupakan faktor pendorong bagi pembentukan akhlak siswa. Motivasi tersebut ada yang berasal dari diri siswa sendiri maupun karena dorongan dari luar diri santri seperti dorongan dari orang tua.

\section{3) Lingkungan Masyarakat}

Masyarakat adalah pelaku atau faktor penting dalam pendidikan dan merupakan lingkungan luas yang mempresentasikan akidah, akhlak, serta nilai-nilai dalam prinsip yang telah ditentukan, karena manusia adalah makhluk sosial, berpengaruh kepada orang lain dan mendapat pengaruh dari orang lain. Tugas masyarakat dalam hal pendidikan meliputi bidang yang cukup luas dan bermacam-macam, yaitu memuat halhal terkecil dalam hidup sampai Departemen-departemen dan sebagainya. Tugas masyarakat juga terlihat dalam kebiasaan dan tradisi serta dalam pemikiran berbagai peristiwa juga dalam kebudayaan secara umum serta dalam pengarahan spiritual dan sebagainya. Oleh karena itu lingkungan masyarakat yang baik kemungkinan besar akan menghasilkan anak yang baik pula.

\section{b. Faktor Penghambat}

Berdasarkan pengamatan dan wawancara dengan para informan, dalam pembentukan akhlak siswa ada beberapa hambatan yang ditemukan, namun hambatan 
itu tidak sampai berakibat serius bagi pembentukan akhlak siswa yang dilaksanakan guru pendidikan agama Islam di SD Pembangunan Laboratorium UNP. Adapun hambatan hambatannya antara lain, sebagai berikut :

\section{1) Tingkat Sosial Ekonomi}

Keberhasilan suatu pendidikan tidak terlepas dari pendanaan yang ada. Sedangkan, masyarakat desa sekitar di SD Pembangunan Laboratorium UNP adalah masyarakat ekonomi menengah ke bawah, sehingga untuk mengembangkan lembaga non formal ini diperlukan donatur dan perjuangan warga yang ikhlas dan rela.

\section{2) Tingkat Pendidikan}

Masyarakat yang berpendidikan tinggi akan selalu memperhatikan pendidikan anaknya. Pendidikan bukan lagi kebutuhan sekunder tetapi sudah menjadi kebutuhan yang harus dipenuhi dalam keluarga. Sedangkan masyarakat desa sekitar SD Pembangunan Laboratorium UNP rata-rata baru menamatkan pendidikan menengah atas (SMA), sehingga menganggap pendidikan merupakan kebutuhan skunder.

\section{Simpulan}

Berdasarkan hasil penelitian dan pembahasan mengenai upaya guru Pendidikan Agama Islam dalam pembentukan akhlak di SD Pembanunan Laboratorium UNP maka dapat disimpulkan hasil penelitian ini antara lain, sebagai berikut : . Akhlaqul Karimah Siswa di SD Pembangunan Laboratorium UNP masih mudah dijumpai siswa yang bertutur kata dengan nada tinggi, berlari-lari di depan kantor guru dan bahkan ada yang rambutnya masih panjang dan ada pula yang memakai anting.

Upaya-upaya yang dilakukan guru Pendidikan Agama Islam dalam pembentukan akhlak siswa yaitu guru Pendidikan Agama Islam memberikan contoh keteladanan melalui kegiatan Tahfiz, guru Pendidikan Agama Islam mendorong siswa agar melaksanakan sholat Dzuhur berjamaah, guru Pendidikan Agama Islam membekali akal pikiran siswa dengan ilmu pengetahuan melalui kisah sejarah, guru Pendidikan Agama Islam menyarankan kepada orangtua siswa agar bergaul dengan orang-orang baik, guru Pendidikan Agama Islam mendorong siswa untuk meninggalkan sifat malas.Faktor yang mendorong dan yang menghambat upaya guru Pendidikan Agama Islam dalam pembentukan akhlak karimah siswa di SD Pembangunan Laboratorium UNP, adapun faktor pendorong pembentukan akhlaqul karimah siswa yaitu kepribadian orangtua, sikap dan cara hidup mereka merupakan unsur pendidikan yang tidak langsung dimana dengan sendirinya akan masuk kedalam pribadi anak yang sedang tumbuh, motivasi siswa dalam mengikuti pembelajaran Pendidikan Agama Islam di kelas, dan masyarakat adalah faktor penting dalam pendidikan dan merupakan lingkungan luas yang mempresentasikan akidah, akhlak, serta nilai-nilai dalam prinsip yang telah ditentukan. Sedangkan faktor pengambat dalam pembentukan akhlaqul karimah siswa, yaitu masyarakat desa sekitar SD Pembangunan Laboratorium UNP adalah masyarakat ekonomi menengah ke bawah, sehingga untuk mengembangkan lembaga nonformal ini diperlukan donatur dan perjuangan warga yang ikhlas dan rela dan masyarakat yang tinggal sekitar SD Pembangunan Laboratorium UNP rata-rata baru menamatkan pendidikan menengah atas (SMA), sehingga menganggap pendidikan merupakan kebutuhan skunder.

\section{Daftar Kepustakaan}

Sagala, P. (2021). Upaya guru pendidikan agama Islam dalam membentuk akhlakul karimah peserta didik di Sekolah Dasar Negeri 07 Panai Hilir Kecamatan Panai Hilir Kabupaten Labuhanbatu (Doctoral dissertation, IAIN Padangsidimpuan). 
Ihsan, Hamdani, Ihsan, Fuad. 2007. Filsafat Pendidikan Islam. Bandung: Pustaka Setia Oemar Hamalik (2014:49) Proses Belajar Mengajar.

Afifuddin, B. A. S., \& Saebani, B. A. (2009). Metodologi penelitian kualitatif. Bandung: Pustaka Setia

Aunillah, N. I. (2011). Panduan menerapkan pendidikan karakter di sekolah. Yogyakarta: Laksana, 80.

Barizi, A., \& Idris, M. (2009). Menjadi guru unggul. Yogyakarta: Ar-ruzz media.

Barnawi \& Arifin, M. (2012). Etika dan profesi kependidikan. Jogjakarta: Ar-Ruzz Media.

Heri, G. (2012). Pendidikan karakter konsep dan implementasi. Bandung: Alfabeta, 7-31.

Hajjaj, M. F. (2011). Tasawuf Islam dan Akhlak, terj. Kamran As ,,at Irsyady dan Fakhri Ghazali. Jakarta: Amzah.

Moleong, L. J. (2008). Metodologi Penelitian Kualitatif edisi revisi Bandung: PT Remaja Rosdakarya Offset.

Muchith, S. (2008). Pembelajaran kontekstual. Semarang: Rasail Media Group.

Samani, M., \& Hariyanto, M. S. (2011). Konsep dan model pendidikan karakter. Bandung: Remaja Rosdakarya.

Nashir, H. (2013). Pendidikan karakter berbasis agama dan budaya. Yogyakarta: Multi Presindo.

Tutuk, N. (2015). Implementasi pendidikan karakter.

Nurfuadi, P. G. (2012). Purwokerto.

Sukardi, M. S. (2006). Penelitian Kualitatif-Naturalistik Dalam Pendidikan. Yogyakarta: Usaha Keluarga.

Saebani, B. A., \& Hamid, A. (2017). Ilmu Akhlak.

Sjarkawi, P. K. A. P. M., \& Intelektual, E. (2006). Sosial Sebagai Wujud Integritas Membangun Jati Diri. Jakarta: PT Bumi Aksara.

Sugiyono, D. (2013). Metode penelitian pendidikan pendekatan kuantitatif, kualitatif dan R\&D. 